\title{
HUBUNGAN PENGETAHUAN KONTRASEPSI SUNTIK DENGAN KEPATUHAN JADWAL PENYUNTIKAN ULANG DI KLINIK JULIANA DALIMUNTHE MEDAN
}

\author{
Nailatun Nadrah ${ }^{1}$, Lina Sartika ${ }^{2}$ \\ ${ }^{1,2}$ STIKes Sehat Medan, Medan \\ Email:nailatunnadrah@gmail.com
}

\begin{abstract}
Abstrak
Kepatuhan dalam melakukan suntik ulang berimbas pada keefektifan kontrasepsi suntik yang digunakan akseptor. Salah satu kegagalan metode kontrasepsi ulang pada akseptor adalah ketidakpatuhan atau keterlambatan akseptor saat melakukan penyuntikan. Wawancara yang dilakukan pada 6 orang Ibu yang datang ke Klinik Juliana dalimunthe Kontrasepsi Suntik DMPA ( $\mathrm{kb}$ suntik 3 bulan) di peroleh informasi bahwa 2 orang Ibu mengatakan sangat patuh untuk melakukan suntik kb sedangkan 4 Ibu mengatakan sering lupa untuk suntik kb. Tujuan penelitian adalah Hubungan Pengetahuan Kontrasepsi Suntik Dengan Kepatuhan Jadwal Penyuntikan Di Klinik Juliana Dalimunthe. Metode penelitian yang digunakan adalah desktiprif analitik dengan pendekatan cros sectional. Populasi adalah semua akseptor suntik DMPA yang melakukan penyuntikan ulang di klinik Juliana dalimunthe. Sampel adalah ibu yang melakukan penyuntikan ulang sebanyak 35 orang. Teknik pengambilan sampel yang digunakan dalam penelitian ini adalah total Sampling.

Berdasarkan hasil analisis bivariat dengan menggunakan uji chi square di peroleh hasil nilai $\rho$ value $=0,006<0.05$, yang berarti ada Hubungan Pengetahuan Kontrasepsi Suntik Dengan Kepatuhan Jadwal Penyuntikan Ulang Di Klinik Juliana Dalimunthe. Dengan mayoritas pengetahuan baik sebanyak 14 Responden dengan kepatuhan patuh sebanyak 11 responden $(78.6 \%)$ dan minoritas pengetahuan kurang sebanyak 10 responden dengan kepatuhan patuh sebanyak 2 responden $(20.0 \%)$. Meningkatkan pemahaman melalui media sosial, media massa dan media cetak tentang pentingnya melakukanpenyuntikan ulang sesuai dengan jadwal yang sudah ditetapkan.
\end{abstract}

Kata kunci: Pengetahuan; Kontrasepsi; Suntik;

\section{Abstract}

Compliance with re-injecting has an impact on the effectiveness of injecting contraceptives used by acceptors. One of the failures of re-contraception methods for acceptors is non-adherence or delays in receiving injections. Interviews were conducted on 6 mothers who came to the Juliana Dalimunthe Clinic for DMPA Injectable Contraception (3 months injectable KB) and obtained information that 2 mothers said they were very obedient to injecting contraception while 4 said they often forgot to re-inject. The purpose of this research is the relationship between mother's knowledge about injectable contraception and adherence to injection schedule at the Juliana Dalimunthe Clinic. The research method used is descriptive analytic with a cross sectional approach. The population is all DMPA injection acceptors who do re-injection at Juliana Dalimunthe clinic. Samples were mothers who re-injected as many as 35 people. The sampling technique used in this study is Accidental Sampling. Based on the results of the bivariate analysis using the chi square test, it was found that the value of value $=0.006<0.05$, which means that there is a correlation between knowledge of injecting contraceptives and adherence to the schedule for re-injection at the Juliana Dalimunthe Clinic. With a majority of good knowledge as many as 14 respondents with obedient compliance as many as 11 respondents (78.6\%) and a minority of less knowledge as many as 10 respondents with obedient compliance as many as 2 respondents (20.0\%). Increase understanding 
through social media, mass media and print media about the importance of re-injecting according to a predetermined schedule.

Keywords: Knowledge; Contraception; Inject;

\section{Pendahuluan}

Indonesia merupakan negara dengan jumlah penduduk yang besar. Setiap tahun jumlah penduduk Indonesia semakin bertambah. Pada tahun 2019, penduduk Indonesia mencapai 267 juta jiwa. Jumlah penduduk yang besar dapat menimbulkan berbagai masalah, seperti melambatnya pertumbuhan ekonomi, meningkatnya pengangguran, dan meningkatnya kriminalitas. Pemerintah terus berupaya membenahi atau menahan proporsi penduduk. Salah satu upaya pemerintah untuk menekan pertumbuhan penduduk di Indonesia adalah Program Keluarga Berencana (KB). Program pelayanan KB penting dalam mewujudkan penduduk Indonesia yang sejahtera, disamping program pendidikan dan kesehatan. Kesadaran akan pentingnya alat kontrasepsi di Indonesia perlu lebih ditingkatkan untuk menghindari pertumbuhan penduduk di Indonesia pada tahun 2016 (BKKBN, 2016).

Penggunaan alat kontrasepsi Akhir-akhir ini suntik cenderung meningkat. Berdasarkan hasil Survei Demografi dan Demografi Indonesia (SDKI) tahun 2018, bentuk penggunaan kontrasepsi terbesar adalah suntik 31,6\%, pil 13,2\%, IUD ,8\%, implan 2,8\%, kondom $1,3 \%$, Kontap wanita $3,1 \%$ kontap pria $0,2 \%$, pantang berkala $1,5 \%$, metode lain $0,8 \%$. Angka penggunaan kontrasepsi suntik meningkat dari tahun 2017 ke tahun 2018 . Tahun 2017 sebesar 11,7\%, tahun 2018 sebesar 15,2\% (BKKBN, 2018).

Suntik KB merupakan satu cara untuk mencegah terjadinya kehamilan dengan melalui suntikan hormonal. Depot Medroxyprogesterone Asetat merupakan jenis kontrasepsi suntik yang diberikan setiap 3 bulan sekali (Rahdiyaningrom dkk, 2021). Suntik $\mathrm{Kb}$ sangat efektif ika diberikan secara teratur dan sesuai jadwal yang telah ditentukan. Pengulangan tepat waktu adalah tepat bagi akseptor karena kegagalan untuk melakukannya dapat mengurangi efektivitas kontrasepsi. Kegagalan pelaksanaan kontrasepsi suntik disebabkan karena keterlambatan ibu yang menerima suntikan tidak sesuai dengan jadwal penyuntikan. (Affandi dkk, 2014). Meskipun kontrasepsi suntik sangat efektif dalam mencegah kehamilan, namun dalam penggunaannya tetap harus diperhatikan karena masalah yang sering muncul pada kontrasepsi suntik adalah keterlambatan akseptor KB dalam menyuntikkan obat. Jika menstruasi terlambat lebih dari 12 minggu dari suntikan terakhir akseptor tanpa perlindungan, kemungkinan besar Anda hamil. Hal ini dapat dipengaruhi karena pengadopsi KB lupa jadwal pemilihan ulang dan mungkin juga dipengaruhi oleh kurangnya pengetahuan dan sikap pengadopsi terhadap kepatuhan (Sukmawati, 2021)

Faktor penyebab ketidakpatuhan adalah pemahaman instruksi, kualitas interaksi, isolasi sosial, keyakinan, sikap, dan kepribadian. Kerugian menggunakan kontrasepsi suntik tanpa jadwal adalah mengarah pada kehamilan, untuk menjawab hal di atas perlu diberikan informasi yang tepat bagi akseptor untuk memilih metode kontrasepsi yang baik, Calon adopter harus diberikan informasi yang tepat. Jelaskan pro dan kontra tentang bagaimana kontrasepsi suntik dapat mengurangi kehamilan dan mengurangi efek samping dari metode ini. (Sulistyowati, 2014)

Berdasarkan survey awal, dari seluruh Pasangan usia subur yang terdata di klinik juliana, sebesar (79\%) adalah peserta KB aktif. Kontrasepsi yang digunakan oleh peserta 
$\mathrm{KB}$ aktif bahwa kontrasepsi yang paling banyak digunakan oleh peserta KB aktif adalah suntik (58\%) dan terbanyak kedua adalah implant (18\%). Jumlah akseptor kontrasepsi suntik di klinik pratamaa Juliana dalimunthe tembung pada bulan maret sampai april 2021 $10,44 \%$ yang melakukan kunjungan ulang tidak sesuai pada jadwal yang telah ditentukan sehingga nanti dapat menyebabkan kehamilan yang tidak direncanakan. Dari hasil wawancara dengan 6 orang Ibu yang datang ke Klinik Juliana dalimunthe Kontrasepsi Suntik DMPA (kb suntik 3 bulan) di peroleh informasi bahwa 2 orang Ibu mengatakan sangat patuh untuk melakukan suntik kb sedangkan 4 Ibu mengatakan sering lupa untuk suntik kb. Berdasarkan latar belakang diatas peneliti tertarik utuk mengetahui hubungan pengetahuan dengan kepatuhan jadwal suntik ulang di klinik Juliana Dalimunthe

\section{Metode Penelitian}

Desain penelitian ini bersifat Analitik yaitu menggambarkan tentang suatu keadaan secara objektif. Dengan pendekatan cross sectional. Populasi penelitian ini adalah akseptor kb suntik 3 bulan sebanyak 35 orang. Cara pengambilan sampel dalam penelitian ini adalah dengan menggunakan teknik total sampling. Instrument yang digunakan pada penelitian kuesioner pengetahuan tentang metode kontrasepsi suntik, untuk menilai pengetahuan dan menggunakan lembar ceklis untuk menilai kepatuhan berdasarkan kartu akseptor, data univariat dan juga analisis bivariat, analisis bivariat dengan menggunakan uji chi square.

\section{Hasil dan Pembahasan}

\section{Hasil Penelitian}

Hasil penelitian diperoleh sebagai berikut:

\begin{tabular}{|c|c|c|}
\hline Karakteristik & Frekuensi & $\%$ \\
\hline \multicolumn{3}{|l|}{ 1. Umur } \\
\hline $20-35$ & 27 & 77.15 \\
\hline $36-45$ & 8 & 22,85 \\
\hline Total & 35 & 100 \\
\hline \multicolumn{3}{|l|}{ 2. Pendidikan } \\
\hline SMP & 4 & 11,43 \\
\hline SMA & 11 & 31,43 \\
\hline Diploma & 15 & 42,86 \\
\hline $\mathrm{S} 1$ & 5 & 14,29 \\
\hline Total & 35 & 100 \\
\hline \multicolumn{3}{|l|}{ 3. Pekerjaan } \\
\hline IRT & 20 & 48,57 \\
\hline Wiraswasta & 15 & 37,14 \\
\hline PNS & 5 & 14,29 \\
\hline Total & 35 & 100 \\
\hline
\end{tabular}

Tabel diatas memperlihatkan bahwa mayoritas adalah ibu dengan rentang usia 2035 yaitu $77,15 \%$ dengan tingkat pendidikan diploma sebanyak $42,86 \%$ dan mayoritas pekerjaan sebagai ibu rumah tangga yaitu 48,57\%. 
Tabel 2 Distribusi Pengetahuan Dan Kepatuhan Responden

\begin{tabular}{|c|c|c|}
\hline Variabel & Frekuensi & $\%$ \\
\hline \multicolumn{3}{|l|}{ 1. Pengetahuan } \\
\hline Baik & 14 & 40.0 \\
\hline Cukup & 11 & 31.4 \\
\hline Kurang & 10 & 28.6 \\
\hline Total & 35 & 100 \\
\hline \multicolumn{3}{|l|}{ 2. Kepatuhan } \\
\hline Patuh & 16 & 45.7 \\
\hline Tidak Patuh & 19 & 54.3 \\
\hline Total & 35 & 100 \\
\hline
\end{tabular}

Dari tabel diatas mayoritas responden berpengetahuan baik sebanyak $40.0 \%$, respondeng dengan pengetahuan cukup yaitu $31,4 \%$ sedangkan pengetahuan kurang sebanyak $28.6 \%$. Responden tidak patuh sebanyak $54.3 \%$, sedangkan responden patuh sebanyak $45.7 \%$.

Tabel 3. Hubungan Pengetahuan Kontrasespsi Suntik Dengan Kepatuhan Jadwal Penyuntikan Ulang Di Klinik Juliana Dalimunthe

\begin{tabular}{lllllllll}
\hline No & Pengetahuan & \multicolumn{6}{c}{$\begin{array}{c}\text { Kepatuhan } \\
\text { Tidak Patuh }\end{array}$} & \multirow{2}{*}{ P Value } \\
\cline { 3 - 6 } & & Patuh & \multicolumn{4}{c}{ Total } & \% & \\
\hline 1. & Baik & 11 & 78.6 & 3 & 21.4 & 14 & 100 & $\mathbf{0 . 0 0 6}$ \\
2. Cukup & 3 & 27.3 & 8 & 72.7 & 11 & 100 & \\
3. & Kurang & 2 & 20.0 & 8 & 80.0 & 10 & 100 & \\
& Total & 16 & 45.7 & 19 & 54.3 & 35 & 100 & \\
\hline
\end{tabular}

Berdasarkan hasil penelitian diperoleh data dari 14 orang ibu yang memiliki pengetahuan baik 11 orang patuh untuk melakukan suntikan ulang sesuai dengan jadwal penyuntikan, setiap orang memiliki pengetahuan yang berbeda, hal ini dapat di pengaruhi oleh lingkungan, pengalaman dan juga keterpaparan informasi (Noriani dkk, 2017). Dari hasil uji chi square diperoleh nilai $\mathrm{p}=0,006(\mathrm{p}<\alpha)$ dapat diinterpretasikan bahwa ada hubungan antara pengetahuan kontrasepsi suntik dengan kepatuhan jadwal penyuntikan sulang di klinik Juliana dalimunthe.

Keluarga Berencana merupakan salah satu cara yang paling efektif untuk meningkatkan ketahanan keluarga, kesehatan, dan keselamatan ibu dan anak serta perempuan. Program Keluarga berencana adalah usaha untuk mengukur jumlah dan jarak anak yang diinginkan (Wa ode, 2017).

Pengetahuan akseptor pada penelitian ini baik sebanyak $40.0 \%$, pengetahuan yang baik tentang suntuk kb ini mempengaruhi kemampuan seseorang dalam memahami dan melaksanakan arahan yang diberikan. Penelitian berasumsi bahwa pengetahuan akseptor yang baik disebabkan oleh mayoritas akseptor berada pada umur 20-35 tahun pada usia tersebut seseorang lebih matang, daya tangkap dan pola piker yang baik. Pengetahuan merupakan informasi antara pemahaman dan potensi yang ada di dalam pikiran. Secara umum, pengetahuan bersifat prediktif tentang sesuatu karena pengenalan 
suatu pola. Pengetahuan merupakan sesuatu yang memegang peranan penting dalam kehidupan, pengetahuan terdiri dari fakta-fakta dan teori-teori tertentu yang memungkinkan seseorang untuk menemukan solusi dari problem. Saifuddin (2003) menyatakan bahwa pada umumnya akseptor lebih memilih metode kontrasepsi suntik karena alasan praktis yaitu sederhana dan tidak perlu takut lupaKontrasepsi suntik memiliki efektifitas yang tinggi bila penyuntikannya dilakukan secara teratur dan sesuai jadwal yang telah ditentukan. Ketepatan waktu untuk suntik kembali merupakan kepatuhan akseptor karena bila tidak tepat dapat mengurangi efektifitas kontrasepsi tersebut. Kegagalan dari metode kontrasepsi suntik disebabkan karena keterlambatan akseptor untuk melakukan penyuntikan ulang.

Kepatuhan akseptor dalam melakukan penyuntikan ulang yaitu tidak patuh sebanyak $54.3 \%$, ketidakpatuhan ini dapat disebebakan oleh kesibukan akan pekerjaan dan pemahaman yang kurang tentang pentingnya ketepatan waktu penyuntikan. Kepatuhan adalah sejauh mana pasien mengikuti rekomendasi klinis dari dokter yang merawatnya. Kepatuhan adalah perilaku pasien yang konsisten dengan ketentuan yang ditetapkan oleh para profesional medis. Kepatuhan dimulai ketika orang mengikuti saran atau instruksi petugas tanpa secara sukarela mengambil tindakan, dan biasanya karena dia ingin menghindari sanksi karena ketidakpatuhan. Kepatuhan adalah salah satu dari faktor yang dipengaruhi oleh pengetahuan (Syakira, 2009)

Hasil penelitian dengan uji chiaquare dengn nilai $\mathrm{p}=0,006$ dapat diinterpretasikan bahwa ada hubungan antara pengetahuan dengan kepatuhan jadwal penyuntikan ulang, yang menyimpulan bahwa semakin baik pengetahuan seseorang maka semakin patuh untuk melalukan penyuntikan ulang tepat waktu. Peneliti berasumsi dari hasil penelitian ini didapatkan bahwa sebagian besar akseptor bepengetahuan baik dengan kepatuhan yaitu 78,6\%. Hal ini menunjukan bahwa akseptor dengan pengetahuan yang baik memiliki tingkat kepatuhan yang tinggi dalam melakukan kunjungan ulang suntikan, sebagian besar ibu melakukan kunjungan ulang suntik tepat waktu karena memiliki tingkat pengetahuan baik tentang kontrasepsi suntik. Bahwa kepatuhan ibu dalam melaksanakan suntik ulang $\mathrm{kb} 3$ bulan berhubungan dengan pengetahuan ibu tentang jadwal dan dampak suntik ulang kontrasepsi, dan juga pemahaman tentang efek dari ketidakpatuhan dalam melakukan suntik ulang harus sesuai dengan jadwal, jika tidak maka dapat menyebabkan terjadinya kehamilan yang tidak diinginkan. Kegagalan dari metode kontrasepsi suntik di sebabkan karena keterlambatan akseptor untuk melakukan penyuntikan ulang.

Sejalan dengan hasil penelitian Krisdiana dkk (2021) tentang kepatuhan suntik ulang yang menyatakan bahwa hubungan yang bermakna antara pengetahuan dengan ketepatan waktu suntik ulang yang dikarenakan p-value yang didapatkan sebesar 0,032 atau $<0,05$. $P R=1,48$ berarti responden yang memiliki pengetahuan kurang memiliki risiko 1,48 kali untuk tidak tepat waktu dibandingkan responden 
dengan pengetahuan cukup atau baik. Hasil Penelitian sukmawati (2021) menunjukan bahwa tingkat pengetahuan tentang kontrasepsi suntik depo progestin di Puskesmas Bara-Barayya Makassar, yang berpengetahuan atau masuk pada kategori tahu sebanyak 49 responden jika dipersentasikan $(80,3 \%)$ sedangkan pada kategori tidak tahu sebanyak 12 responden $(19,7 \%)$ dari 61 responden.

\section{Kesimpulan}

Hasil penelitian menyimpulkan bahwa 40,0\% ibu memiliki pengetahuan baik, dan ibu memiliki pengetahuan baik dengan patuh sebanyak 11 responden $(78.6 \%)$ Sedangkan nilai p-value pada tabel diatas 0.06 maka $(\mathrm{p})<0.05$ maka ada Hubungan Pengetahuan Kontrasepsi Suntik Dengan Kepatuhan Jadwal Penyuntikan Ulang Di Klinik Juliana Dalimunthe.

\section{Referensi}

Affandi. 2014. Buku Panduan Praktis Pelayanan Kontrasepsi. Jakarta.

Anggraini dan Martini. 2012. Pelayanan Keluarga berencana. Yogyakarta: Rohima press.

BKKBN. 2016. Kebijakan Program Kependudukan, Keluarga Berencana dan Pembangunan Keluarga dalam Mendukung Keluarga Sehat. PT. Bina Pustaka, Jakarta.

Krisdiana, R., \& So, E. Hubungan Antara Pengetahuan Akseptor Kb Suntik Dengan Ketepatan Waktu Suntik Kb Di Bps Khanifah, Kabupaten Tangerang, Propinsi Banten Periode Januari-Desember 2017. Ebers Papyrus, 27(1), 26-33.

Noriani, N. K., Nurtini, N. M., \& Indriana, P. R. K. (2019). Hubungan Pengetahuan dan Motivasi Akseptor KB Suntik 3 Bulan dengan Kepatuhan Kunjungan Ulang di BPM Koriawati tahun 2017. Jurnal Riset Kesehatan Nasional, 3(2), 35-39.

Rahdiyaningrom, R., Prasetyowati, E., \& Adelia, D. D. (2021). Hubungan Antara Tingkat Pengetahuan Tentang Kontrasepsi Suntik 3 Bulan Dengan Kepatuhan Jadwal Penyuntikan Ulang Suntik 3 Bulan Di Bps Ani Latifah Tirtoyudo Kabupaten Malang. Biomed Science, 8(1), 9-20.

Saifuddin, A. B. 2003. Panduan Praktis Pelayanan Kontrasepsi.Yayasan Bina Pustaka.Sarwono Prawirohardjo, Jakarta

Sulistyawati, A.2014. Pelayanan Keluarga Berencana. Salemba Medika, Jakarta.I

Sukmawati, S. (2021). Hubungan Tingkat Pengetahuan Dan Sikap Ibu Dengan Kepatuhan Jadwal Penyuntikan Ulang Depo Progestin Di Puskesmas Bara-Barayya Makassar. Jurnal Ilmiah Keperawatan Dan Kebidanan Holistic Care, 5(1). 
Syakira. 2009. Psikologi Untuk Kebidanan.

Wa Ode Mesrawati, P. (2017). Hubungan Pengetahuan Ibu Tentang Kontrasepsi Suntik Depo Medroksi Progesteron Acetate (Dmpa) Dengan Kepatuhan Jadwal Penyuntikan Ulang Di Wilayah Kerja Puskesmas Waetuno Kabupaten Wakatobi Tahun 2017 (Doctoral Dissertation, Poltekkes Kemenkes Kendari). 